\title{
Stratigraphy of the intra-crater volcaniclastic deposits of the Victor Northwest kimberlite (Canada)
}

\author{
Bram I. van Straaten, ${ }^{1, *}$, M. G. Kopylova ${ }^{1}$, J. K. Russell ${ }^{1}$, \\ K. J. Webb ${ }^{2,3}$ and B. H. Scott Smith ${ }^{4,1}$ \\ ${ }^{1}$ Department of Earth and Ocean Sciences, University of British Columbia, Canada $;{ }^{2}$ De Beers \\ Canada Inc., Exploration Division, ${ }^{3}$ Now at: Mineral Services Canada Inc.; ${ }^{4}$ Scott-Smith \\ PetrologyInc., Canada. ${ }^{*}$ bvanstraaten@eos.ubc.ca / phone: +1 604-8220671
}

\section{INTRODUCTION}

The Victor kimberlite is located in the James Bay Lowland, Northern Ontario. Production of diamonds from the open pit mine started in early 2008. The Victor Northwest pipe (diameter $\sim 300 \mathrm{~m}$ ) forms part of a Middle-Late Jurassic volcanic complex comprising several adjacent and cross-cutting kimberlite pipes. These steep-sided $\left(\sim 70^{\circ}\right)$ pipes occur in a $\sim 275 \mathrm{~m}$ thick Palaeozoic sedimentary succession, unconformably overlying granitoid basement (Fig. 1). Since emplacement, the upper part of the pipes have been eroded, and currently the kimberlite pipes are overlain by $\sim 10-30 \mathrm{~m}$ of unconsolidated overburden.

This contribution documents the complex internal stratigraphy of Victor Northwest (VNW), one of the early-formed kimberlite pipes in the complex. The stratigraphic relations documented here are used to interpret the emplacement of this kimberlite pipe (van Straaten et al., this volume).

\section{INTRA-CRATER STRATIGRAPHY}

Twenty-two drill cores were available to reconstruct the three dimensional volcanic facies distribution within the VNW pipe. This study identified thirteen distinct volcanic facies characterised by contrasting textures as well as stratigraphic position within the pipe. Texturally, spatially and/or temporally related facies are grouped into five facies associations. Below, these five facies associations and their individual facies are described from depth to surface.

\section{Lower facies association (FA 1)}

FA 1 comprises two volcanic facies: facies 1a occurs as a thin veneer on the lower pipe wall (7$18 \mathrm{~m}$ thick, measured perpendicular to the pipe wall; Fig. 1). This facies is a bedded, variably country rock fragment (CRF) rich ( 25-45 vol.\%), ash-rich, volcaniclastic kimberlite. Facies $1 \mathrm{~b}$ overlies facies $1 \mathrm{a}$, and is volumetrically much more extensive. This facies is interpreted to occupy the entire central and deeper portion of

Figure 1: Cross section through the VNW pipe showing the 5 facies associations and 13 individual facies. Green denotes sedimentary country rock breccia bodies, reds are volcaniclastic kimberlite and blues indicate dense, dark and competent lithologies. Extrapolated areas are lighter coloured. Inset shows location of cross section. the VNW pipe, from around 200 meters below the present surface (mbs) to at least $396 \mathrm{mbs}$ (deepest intersection of VNW kimberlite). Facies $1 \mathrm{~b}$ is a dark, dense, competent, massive, CRF-poor ( $\sim 3-8$ vol.\%), matrix- to clast-supported kimberlite. Both facies 1a and $1 \mathrm{~b}$ contain broken olivines (Fig. 2b), and the abundance of broken olivine generally decreases upward and away from the lower pipe wall.

The central and deeper part of facies $1 \mathrm{~b}$ contains minor intervals characterised by higher $\mathrm{CRF}$ abundances and more clast-supported textures. In both facies $1 \mathrm{a}$ and the central and deeper part of facies $1 \mathrm{~b}$, thin fine-grained envelopes around olivine or CRF kernels are present. These envelopes contain small broken olivines and thus represent clastic (or ash armoured) pyroclasts (Fig. 2a). Contacts between facies $1 \mathrm{a}$ and $1 \mathrm{~b}$ are gradational in nature. Contact relationships and the textural evidence presented above indicate that facies $1 \mathrm{~b}$ is clastic in origin. However,

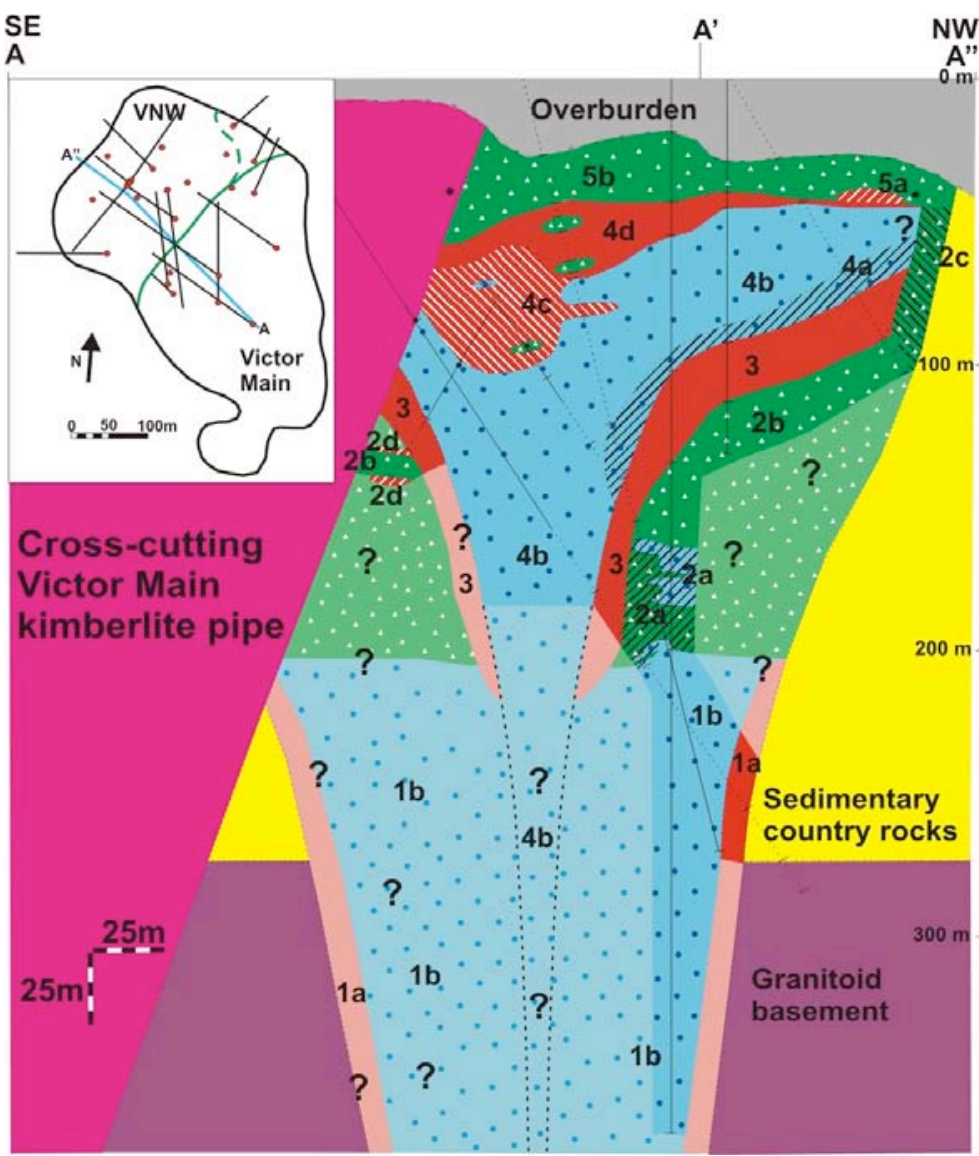


certain intervals in the upper and central part of facies $1 \mathrm{~b}$ appear to be coherent in nature, as indicated by the dark, dense and featureless appearance, presence of only minor broken olivines, fairly evenly distributed olivines and, importantly, a well crystallised groundmass (similar to facies $4 \mathrm{a} / \mathrm{b}$, see Fig. 3b).

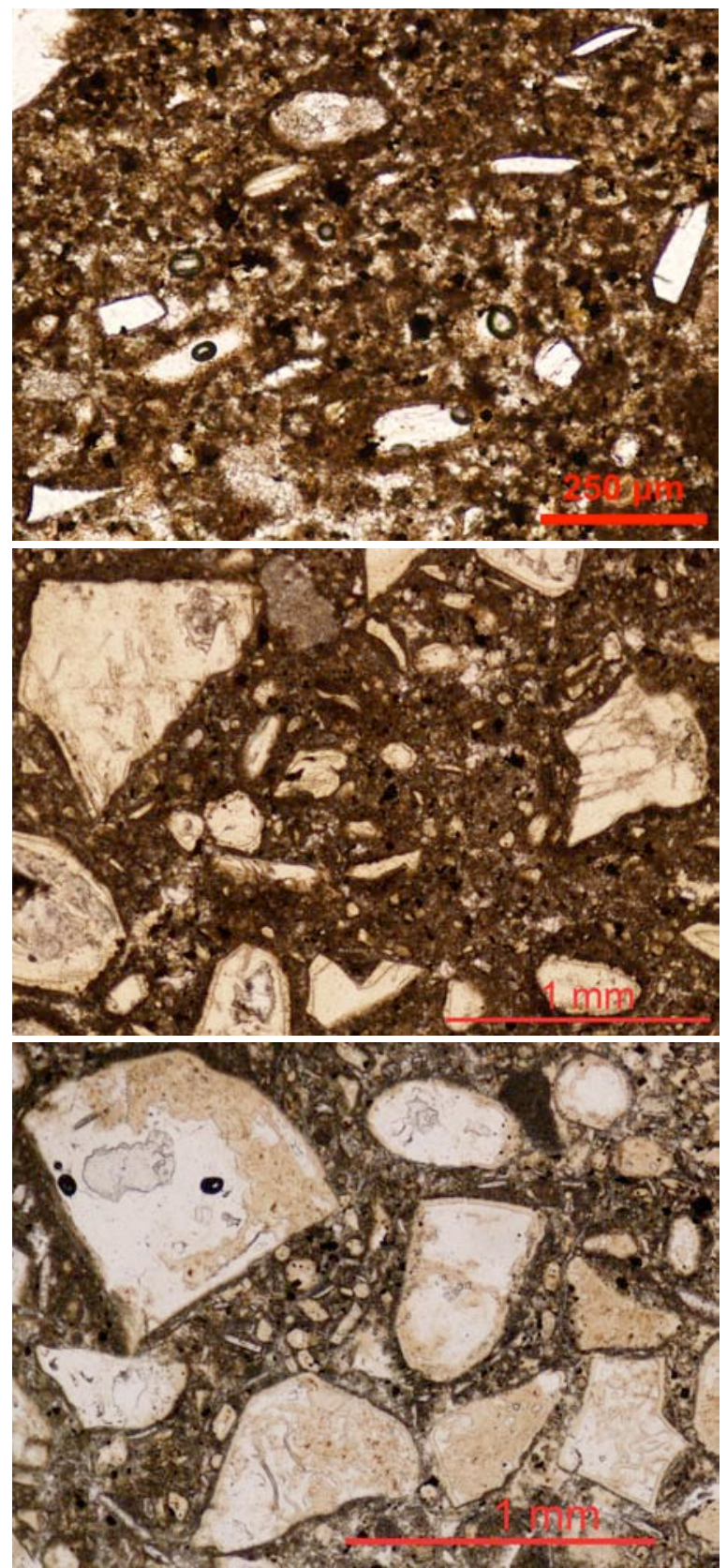

Figure 2: Broken olivines in (a) a thin fine grained envelope around a larger olivine (outside of field of view) of facies 1a, (b) the outer and lower part of facies $1 b$, and (c) facies 3 .

\section{Lower-central facies association (FA 2)}

FA 2 is dominated by a distinct breccia (facies $2 \mathrm{~b}$ ) that is $\sim 10-40 \mathrm{~m}$ thick and comprises a mixture of various $10 \mathrm{~cm}-\mathrm{m}$ scale sedimentary country rock clasts. The contact of FA 2 with the underlying facies (1b) is intersected in six drill cores. The upper part of facies $1 \mathrm{~b}$ is generally characterised by an upward increase in CRF abundance, and in certain cases a separate facies (facies 2a) can be distinguished. This facies commonly consists of alternating volcaniclastic kimberlite, dark, dense and competent kimberlite and sedimentary country rock breccia. The dark and dense kimberlite generally contains minor broken olivines and is similar to the dark, dense and coherent-looking kimberlite in the upper and central part of facies $1 \mathrm{~b}$.

Facies $2 \mathrm{c}$ is a pipe-marginal, dominantly monolithic sedimentary country rock breccia $(\sim 23 \mathrm{~m}$ thick, measured perpendicular to the pipe wall). This facies is intersected in only one drill core; no other drill cores intersect the central to upper pipe contact. A number of drill cores intersect minor $(\sim 5 \mathrm{~m})$ resedimented kimberlite: facies $2 \mathrm{~d}$. This facies is generally found overlying the country rock breccia, although one drill core intersects resedimented kimberlite both above and below/within the country rock breccia. Facies $2 \mathrm{~d}$ is characterised by bedded, relatively well-sorted, closely-packed, generally CRFrich ( 25-50 vol.\%) kimberlite deposits, these features suggest deposition into a local body of standing water.

\section{Upper-central facies association (FA 3)}

The basal contact of FA 3 (as observed in 12 drill cores) defines a concentric funnel-shaped depression within the larger VNW pipe fill. The geometry, together with the occurrence of cognate lithic clasts in the base of the deposit, suggests a cross-cutting nested crater was formed prior to and/or during deposition of this facies.

FA 3 is made up of only one facies: facies 3 . This facies is a $16-32 \mathrm{~m}$ thick, bedded, CRF-rich $(\sim 15-40$ vol.\%) volcaniclastic kimberlite, which is matrix- to clast-supported and contains abundant small $(<1-2 \mathrm{~cm})$ and variable amounts of larger CRFs. The juvenile pyroclasts in this unit range from $50 \mu \mathrm{m}$ juvenile ash particles to $3 \mathrm{~mm}$ uncored, irregular juvenile pyroclasts, which are variably vesicular $(0-20 \%)$. The matrix-supported intervals are regarded as ash-rich volcaniclastic deposits. Additional components of this facies include common broken olivine crystals (Fig. $2 \mathrm{c}$ ), and accretionary pyroclasts of ash with fine ash rims.

\section{Upper facies association (FA 4)}

FA 4 contains four individual facies, of which only facies $4 \mathrm{a}$ and $4 \mathrm{~b}$ are volumetrically extensive. Facies $4 \mathrm{a}$ and $4 \mathrm{~b}$ combined range in thickness from $45 \mathrm{~m}$ (near pipe margins) to $>110 \mathrm{~m}$ (near pipe centre), and occur stratigraphically above facies 3 and 2c (Fig. 1). Facies $4 \mathrm{a}$ is distinguished from facies $4 \mathrm{~b}$ largely on the basis of its finer grain size (largest dominant olivines are 1-5 $\mathrm{mm}$ vs. 2-10 $\mathrm{mm}$ ), and more common occurrence of patchy grain size variations and clast-supported areas. Facies $4 \mathrm{a}$ lies below facies $4 \mathrm{~b}$ and is about $12 \mathrm{~m}$ thick. Both facies $4 \mathrm{a}$ and $4 \mathrm{~b}$ consist of dark, dense, competent, massive, CRF-poor ( 2-10 vol.\%), matrixsupported kimberlite that has gradational contacts with the volcaniclastic facies above and below. Bedding is rare to absent, although a subhorizontal preferred alignment of grains (fabric) is commonly observed (Fig. 3a). Broken olivines are present but not common. The fabric of these rocks and the presence of patchy grain size variations (Fig. 3a), clast-supported areas, and faint pyroclast outlines suggest that the dominant part of these facies is clastic in origin. However, certain 
intersections in these facies appear to be coherent, as indicated by the dark, dense and featureless appearance, the uniform distribution of olivine and presence of a well crystallised groundmass (Fig. 3b).

Facies $4 \mathrm{c}$ is a small volume $(\sim 50 \times 50 \times 40 \mathrm{~m}) \mathrm{CRF}-$ poor ( $\sim 6$ vol. $\%)$, mostly clast-supported volcaniclastic kimberlite that occurs in the centre of the pipe (Fig. 1). It displays local graded bedding and is characterized by variable, but generally higher, proportions of discrete olivines (crystal without melt selvage) to juvenile pyroclasts (crystal with melt selvage). Facies $4 d$ is a laterally continuous, $\sim 5-27 \mathrm{~m}$ thick, CRF-rich $(\sim 10-40$ vol.\%), clast- to matrix-supported, bedded volcaniclastic kimberlite that overlies all other facies, and grades upwards into country rock breccias (FA 5). Facies $4 \mathrm{~d}$ comprises mainly discrete olivines and minor round-ovoid shaped juvenile pyroclasts. Graded beds (1-6 m thick) are common and country rock breccia intervals (4-5 m thick) occur locally within this facies.

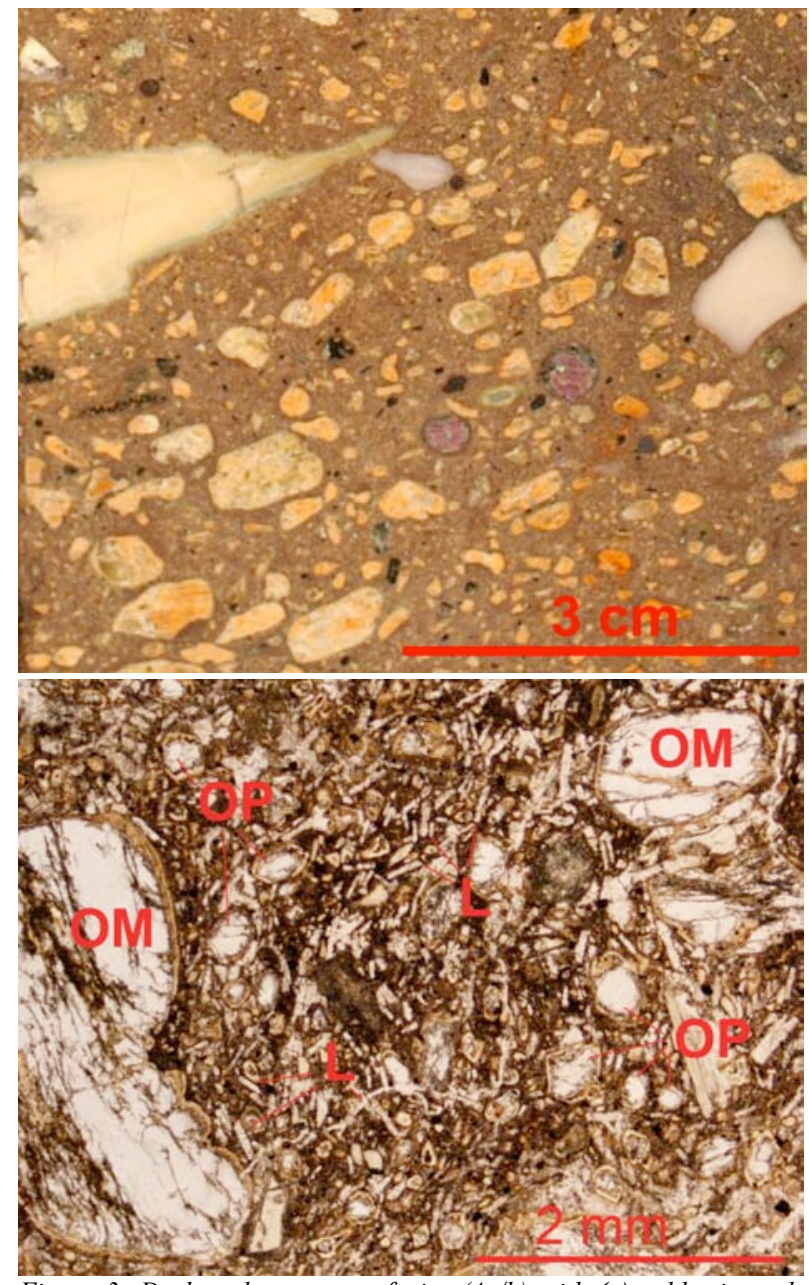

Figure 3: Dark and competent facies (4a/b) with (a) subhorizontal fabric and patchy grain size variation, and (b) coherent kimberlite composed of olivine macrocrysts $(O M)$, olivine phenocrysts $(O P)$ and well crystallised groundmass with opaque minerals and carbonate laths (L).

\section{Uppermost facies association (FA 5)}

One drill core intersects a short interval $(\sim 3 \mathrm{~m})$ of in situ kimberlitic sediments (facies 5a) between the underlying volcaniclastic kimberlite (facies 4d) and overlying country rock breccia (facies 5 b). Small-scale soft-sediment slump features, cross-bedding, fining upward sequences with coarser quartz-rich lag deposits and massive to laminated mudstone intervals (Fig. 4) are all indicative of the presence of a small body of standing water at the time of deposition.

The bulk of FA
5 comprises a sedimentary country rock breccia (facies 5b) that ranges in thickness from 11 to $24 \mathrm{~m}$ (increasing to $35 \mathrm{~m}$ near the pipe wall). This facies consists of various types of large sedimentary country rock clasts (siltstones, limestones, dolostones clasts

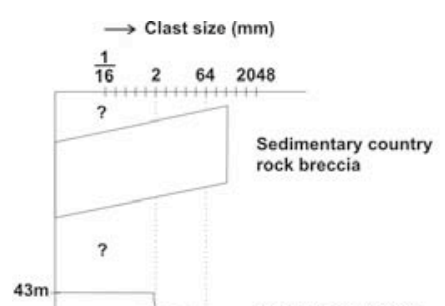
mudstones), with minor or no interclast kimberlite. Core loss is typically high in this facies.

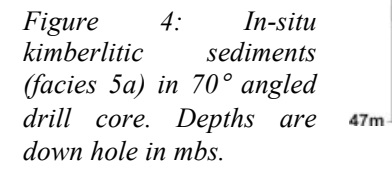

\section{SUMMARY AND CONCLUSIONS}

The Victor Northwest kimberlite pipe fill provides an example of the possible degree of complexity and small-scale variability within intra-crater volcanic deposits. The VNW pipe comprises numerous contrasting small-volume volcanic facies, including dark and coherent-looking kimberlite, sedimentary country rock breccias, volcaniclastic kimberlite, resedimented volcaniclastic kimberlite, and kimberlitic sediments.

The kimberlite deposits described above record an oscillation between variably explosive eruptions (facies associations 1, 3 and 4) vs. mass wasting and resedimentation events (facies associations 2 and 5). A detailed interpretation of the emplacement history of the VNW kimberlite pipe is presented by van Straaten et al. (this volume).

\section{ACKNOWLEDGEMENTS}

We thank De Beers Canada for their financial and logistical support, and NSERC for a research grant to MGK and JKR.

\section{REFERENCES}

van Straaten, B.I., Kopylova, M.G., Russell, J.K., Webb, K.J. and Scott Smith, B.H. (this volume). Explosive fragmentation and eruption of kimberlite, insights from the Victor Northwest pipe (Canada). 